\title{
KONTRIBUSI MUSYAWARAH KELOMPOK KERJA GURU (KKG) DAN MOTIVASI KERJA TERHADAP KEMAMPUAN MERENCANAKAN PEMBELAJARAN
}

\author{
RIDWAN HATALA \\ Dosen Prodi Pendidikan Pancasila dan Kewarganegaraan-FKIP Unpatti \\ email.hatalaridwan78@gmail.com
}

\section{ARTICLE INFO}

\section{Article History:}

Accepted 5 Agustus 2019

Available Online 2 Oktober 2019

Keywords:

Musyawarah Kelompok Kerja Guru (KKG), Motivasi Kerja dan Kemampuan Merencanakan Pembelajaran.

\section{ABSTRACT}

Penelitian ini bertujuan untuk mengetahui sebarapa besar kontribusi pelaksanaan musyawarah Kelompok Kerja Guru (KKG) dan Motivasi Kerja Guru sebagai variabel bebas terhadap Kemampuan Merencanakan Pembelajaran sebagai variabel terikat baik secara sendiri-sendiri maupun secara bersama-sama.

Penelitian ini dilakukan di Kecamatan Salahutu Kabupaten Maluku Tengah khususnya terhadap guru-guru SD yang yang aktif sebagai anggota KKG pada Gugus Liang Kecamatan Salahutu Kabupaten Maluku Tengah. Tipe penelitian ini adalah penelitian kuantitatif dengan pendekatan korelasional.

Hasil pengujian hipotesis pertama menunjukan bahwa pelaksanaan Muswawarah Kelompok Kerja Guru (KKG) memiliki Hubungan yang berarti (signifikan) dengan kemampuan merencanakan pembelajaran. Hubungan ini terlihat dari angka korelasi $\left(r_{\mathrm{y} .1}\right)=$ 0,502 dengan koefisien diterminasi sebesar 0,2521 pada taraf $\alpha=0,05$. Pengujian hipotesis kedua juga menunjukkan bahwa motivasi kerja mempunyai Hubungan yang berarti terhadap 


kemampuan merencanakan pembelajaran.
Hubungan ini terlihat dari angka korelasi $\left(\mathrm{r}_{\mathrm{y} .2)=}\right)$
0,609 dengan koefisien diterminasi sebesar
0,3718 pada $\alpha=0,05$. Hasil pengujian hipotesis
ketiga, pelaksanaan KKG dan motivasi kerja
secara bersama-sama mempunyai hubungan yang
berarti terhadap kemampuan merencanakan
pembelajaran. Besarnya hubungan tersebut
ditunjukkan oleh koefisien korelasi $\mathrm{r}$ sebesar
0,703 dengan uji $\mathrm{F}$, di mana F hitung $15,816>\mathrm{F}$
tabel 3,3403 pada taraf $\alpha=0,05$.

\section{PENDAHULUAN}

Perencanaan pembelajaran merupakan tugas utama yang perlu dilakukan guru sebelum proses belajar mengajar dimulai. Hal ini agar guru dapat mengorganisasikan dan menyajikan pelajaran di depan kelas dengan sistematis sehingg tujuan pembelajarannya dapat dicapai. Guru dituntut untuk memaksimalkan semua potensi kemampuaan profesionalisme yang dimilikinya agar peserta didiknya dapat mencapai tujuan pembelajaran seperti yang telah direncanakan.

Menyadari akan pentingnya peranan dan tanggung jawab guru dalam pelaksanaan proses belajar mengajar serta dalam peningkatan mutu pendidikan dan pengajaran di sekolah-sekolah, pemerintah telah melakukan berbagai upaya untuk merealisasikan peningkatan mutu pendidikan dan pengajaran tersebut, antara lain; a) memantapkan pelaksanaan kurikulum yang berlaku, b) meningkatkan jumlah sarana dan prasarana untuk lebih memeratakan pelayanan pendidikan, c) meningkatkan jenis dan jumlah guru, baik secara kuantitatif maupun kualitatif, sebagai kelanjutan usaha peningkatan dan pemerataan mutu melalui pendidikan dan pelatihan (diklat), d) meninhgkatkan jenis dan jumlah sarana pendidikan dalam upaya peningkatan mutu, e) melaksanakan berbagai kegiatan ekstra kurikuler sebagai usaha mendidik murid untuk ikut serta melakukan kegiatan kemasyarakatan, f) meningkatkan kegiatan olah raga, kesenian, dan keterampilan dalam kegiatan intra kurikuler, kemudian peningkatan interaksi sesama guru melalui organisasi profesi dan sistem pembinaan profesional guru yang dilaksanakan melalui wadah terbentuk. segenab usaha yang telah dilakukan masih belum membawa hasil sesuai apa yang dihendaki oleh dunia pendidikan.

Suatu kegiatan yang direncanakan secara matang sebelumnya, akan lebih maksimal pencapai tujuannya dan akan lebih berhasil dibanding dengan yang tidak mempunyai perencanaan sebelumnya. Kemp (1994:13) menyatakan bahwa kemampuan merencanakan pengajaran meliputi 10 hal yaitu : 1) perkiraan kebutuhan belajar untuk merancang suatu program pengajaran, nyatakan tujuan, kendala dan prioritas yang harus diketahui, 2) pilih pokok bahasan atau tugas untuk dilaksanakan dan tunjukkan tujuan umum yang akan dicapai, 3) teliti ciri siswa yang harus mendapat perhatian selama perencanaan, 4) tentukan isi pelajaran dan uraikan unsur tugas yang berkaitan dengan tujuan, 5) nyatakan tujuan belajar yang akan dicapai dari segi isi 
pelajaran dan unsur tugas, 6) rancangan kegiatan belajar mengajar untuk mencapai tujuan yang sudah dinyatakan, 7) pilih sejumlah media untuk mendukung kegiatanan pengajaran, 8) rincikan pelayanan penunjang yang diperlukan untuk mengembangkan dan melaksanakan semua kegiatan dan untuk memperoleh atau membuat bahan, 9) bersiap-siap untuk mengevaluasi hasil belajar dan hasil program, dan 10) tentukan persiapan siswa untuk mempelajari pokok bahasan dengan memberikan uji-awal kepada mereka.

Kelompok Kerja Guru adalah suatu wadah kerja sama guru-guru sekolah dasar yang dijadikan sebagai tempat mendiskusikan masalah-masalah yang berkaitan dengan kemampuan profesional, yaitu dalam hal merencanakan, melaksanakan, dan menilai kemajuan siswa. Pada KKG guru-guru dapat mendiskusikan berbagai masalah yang berguna untuk meningkatkan proses belajar mengajar serta memikirkan secara bersama-sama kemungkinan pemecahannya berdasarkan pengalaman dan ide-ide yang bersumberkan juga dari masing-masing guru-guru pengikut KKG tersebut. Adapun dasar pelaksanaan kegiatan ini adalah : Keputusan Direktur Jendral Pendidikan Dasar dan Menengah nomor 079/C/KEP/1993 tanggal 7 April 1993 tentang Pedoman Pelaksanaan Sistem Pembinaan Profesional Guru melalui Pembentukan gugus sekolah di sekolah dasar (depdikbud : 1996/1997 :46). Tujuan kegiatan KKG yang merupakan bahagian dari komponen Gugus sekolah adalah agar para guru SD dapat memperlancar upaya peningkatan kemampuan profesional diri dalam meningkatkan mutu proses dan hasil belajar siswa dengan mendayagunakan segala sumber daya dan potensi yang dimiliki oleh sekolah, tenaga kependidikan dan masyarakat sekitar. (Depdikbud : 1997/1998)

Agar kegiatan KKG tersebut benar-benar mengarah pada pencapaian tujuan yang ingin dicapai, maka seluruh unsur yang terlibat dalam pengelolaan kegiatan tersebut yakni Kepala Sekolah dan Pengawas Sekolah juga dari pada Tutor dan Guru Pemandu Mata Pelajaran dan perangkat gugus, dituntut kemampuannya untuk melaksanakan tugas sesuai menurut posisi masing-masing secara baik dan konsekuen, dalam artian tugas yang berdasarkan pedoman atau aturan yang telah ditetapkan, juga dituntut untuk menciptakan iklim kerja yang kondusif dalam kebersamaan antar sesama pengelola.

Terry (1990:17) mendefinisikan bahwa perencanaan adalah menetapkan pekerjaan yang harus dilaksanakan oleh kelompok untuk mencapai tujuan yang digariskan, planning mencakup kegiatan pengambilan keputusan, karena termasuk pemilihan alternatif-alternatif keputusan. Selanjutnya Dharma (1985 :84) mengemukakan bahwa proses perencanaan yang baik meliputi langkah-langkah : 1) identifikasi tujuan umum, 2) menetapkan sasaran, 3) menyusun rencana pelaksanaan, dan 4) spesifikasi standart kontrol. Sedangkan Handoko (1984 : 23) mengatakan bahwa perencanaan adalah : 1) pemilihan atau penetapan-penetapan tujuan organisasi dan 2) penentuan strategi, kebijaksanaan, proyek, program, prosedur, metode, sistem, anggaran dan standar yang dibutuhkan untuk mencapai tujuan.

John P. Campbell, dkk mengemukakan bahwa motivasi mencakup di dalamnya arah atau tujuan tingkah laku, kekuatan respons, dan kegigihan tingkah laku. Di samping itu, istilah tersebut mencakup sejumlah konsep dorongan (drive), kebutuhan (need), rangsangan (incentive), ganjaran (reward), penguatan (reinforcement), 
ketetapan tujuan (goal setting), harapan (expectancy), dan sebagainya. Sedangkan menurut Handoko ( 1999 ), motivasi diartikan sebagai keadaan dalam pribadi seseorang yang mendorong keinginan individu untuk melakukan kegiatan - kegiatan tertentu. Menurut Malthis ( 2006 , 114 ), motivasi adalah keinginan dalam diri seseorang yang menyebabkan orang tersebut bertindak. Biasanya orang bertindak karena suatu alasan untuk mencapai tujuan. Memahami motivasi sangatlah penting karena kinerja, reaksi terhadap kompensasi dan persoalan sumber daya manusia yang lain dipengaruhi dan mempengaruhi motivasi.

Motivasi kerja merupakan motivasi yang terjadi pada situasi dan lingkungan kerja yang terdapat pada suatu organisasi atau lembaga. Keberhasilan dan kegagalan pendidikan memang sering dikaitkan dengan motivasi kerja guru. Pada dasarnya manusia selalu menginginkan hal yang baik-baik saja, sehingga daya pendorong atau penggerak yang memotivasi semangat kerjanya tergantung dari harapan yang akan diperoleh mendatang jika harapan itu menjadi kenyataan maka seseorang akan cenderung meningkatkan motivasi kerjanya. Uno (2008: 66-67), menjelaskan motivasi kerja adalah sebagai 1) aktivitas dasar dan dijadikan bagian esensial dari kehidupan manusia, 2) kerja itu memberikan status, dan mengikat seseorang kepada individu lain dan masyarakat, 3) pada umumnya wanita atau pria menyukai pekerjaan, 4) moral pekerja dan pegawai itu banyak tidak mempunyai kaitan langsung dengan kondisi fisik maupun materiil dari pekerjaan.

\section{METODE PENELITIAN}

Penelitian ini adalah penelitian kuantitatif dengan pendekatan korelasional yang bertujuan untuk mengetahui sebarapa besar kontribusi atau sumbangan pelaksanaan KKG (Kelompok Kerja Guru) dan Motivasi kerja Guru sebagai variabel bebas terhadap kemampuan merencanakan pembelajaran sebagai variabel terikat baik secara sendirisendiri maupun secara bersama-sama. Penelitian ini dilakukan di Kecamatan Salahutu Kabupaten Maluku Tengah khususnya terhadap guru-guru Sekolah Dasar (SD) yang yang aktif sebagai anggota KKG pada Gugus Liang Kecamatan Salahutu.

Hipotesis Penelitian

Berdasarkan kajian teoretis dan kerangka berpikir di atas, maka hipotesis dalam penelitian ini adalah sebagai berikut :

1. Terdapat hubungan yang signifikan antara pelaksanaan Kelompok Kerja Guru (KKG) terhadap kemampuan merencanakan pembelajaran.

2. Terdapat hubungan yang signifikan antara motivasi kerja terhadap kemampuan merencanakan pembelajaran

3. Terdapat hubungan yang signifikan antara pelaksanaan kegiatan Kelompok Kerja Guru (KKG) dan Motivasi Kerja secara bersama-sama terhadap Kemampuan Merencanakan Pembelajaran. 


\section{HASIL PENELITIAN DAN PEMBAHASAN}

Setelah dilakukan pengambilan data melalui penyebaran angket untuk variabel $\mathrm{X}_{1}$ dan $\mathrm{Y}$ serta tes kemampuan untuk variabel $\mathrm{X}_{2}$, berikut ini akan diuraikan hasil penelitian yang berisikan deskripsi data, pengujian persyaratan analisis dan pengujian hipotesis.

1. Hubungan antara Pelaksanaan KKG (Kelompok Kerja Guru) $\left(\mathrm{X}_{1}\right)$ terhadap Kemampuan Merencanakan Pembelajaran (Y)

Berdasarkan hipotesis yang telah di ajukan khusus hipotesis pertama yakni "terdapat hubungan yang signifikan antara pelaksanaan musyawarah KKG dengan kemampuan merencanakan pembelajaran", maka berdasarkan analisis data variabel $\mathrm{X}_{1}$ dan Y diperoleh $r=0,502, r^{2}=0,2521$. Selanjutnya setelah dilakukan uji t diperoleh $t_{\text {hitung }}=3,0725$. Sedangkan $t_{\text {tabel }}$ pada taraf $\alpha=0,05$ sebesar 2,0422. Dari hasil analisa tersebut dapat disimpulkan bahwa terdapat hubungan yang signifikan antara pelaksanaan KKG $\left(\mathrm{X}_{1}\right)$ dengan kemampuan merencanakan pembelajaran $(\mathrm{Y})$ dengan indeks korelasi sebesar 0,502 dengan diterminasi $\left(r^{2}\right)$ 0,2521 atau 25,21\%.

Jika dilakukan pengontrolan terhadap variabel bebas yang lain, maka diperoleh koefisien korelasi parsial $r_{y} 1-2$ sebesar 0,516 dengan koefisien diteminasi $r^{2}=0,2670$. Setelah dilakukan uji t, diperoleh $t_{\text {hitung }}=4,1376$. Sedangkan $t_{\text {tabel }}$ pada taraf $\alpha=0,05$ sebesar 2,0017. Dari hasil perhitungan tersebut ternyata $t_{\text {hitung }}>t_{\text {tabel }}$ pada taraf $\alpha=$ 0,05 . Bila dilakukan pengontrolan terhadap variabel bebas yang lain dalam hubungan $\mathrm{x}_{1-\mathrm{y}}$, ternyata tidak terjadi peningkatan kadar hubungan antara keduanya. Artinya hubungan kedua variabel tersebut tetap signifikan meskipun dilakukan pengontrolan terhadap variabel lainnya. Hal ini diperkuat oleh hubungan variabel $\mathrm{X}_{1}$ sebesar $26,70 \%$ terhadap Y.

Berdasarkan hasil perhitungan model regresi hubungan antara pelaksanaan KKG dengan kemampuan merencanakan pembelajaran (Y) dapat dinyatakan dalam bentuk persamaan $\hat{\mathbf{Y}}=\mathbf{5 7 , 9 0}+\mathbf{0 , 4 9} \mathrm{X}_{\mathbf{1}}$. Untuk menguji keberartian dan linearitas hubungan antara $\mathrm{X}_{1}$ dengan $\mathrm{Y}$ tersebut dil)kukan analisis varians. Perhitungannya disajikan dalam tabel erikut.

\section{Tabel 1}

Hasil Analisis Varians Regresi Linear $X_{1}$ dan $Y$

$\hat{\mathbf{Y}}=\mathbf{5 7 , 9 0}+\mathbf{0 , 4 9} \mathrm{X}_{1}$

\begin{tabular}{|c|c|c|c|c|c|c|}
\hline $\begin{array}{c}\text { Sumber } \\
\text { Varian }\end{array}$ & $\mathbf{d k}$ & $\mathbf{J K}$ & $\mathbf{K T}$ & $\mathbf{F}$ hitung & $\begin{array}{c}\mathbf{F} \text { tabel } \\
\mathbf{\alpha}=\mathbf{0 , 0 5}\end{array}$ & Keterangan \\
\hline Total (T) & 30 & 208929,80 & & & & \\
\hline Regresi (a) & 1 & 14050,15 & - & - & - & \\
\hline $\begin{array}{c}\text { Regresi } \\
\text { (b/a) }\end{array}$ & 1 & 208929,80 & 208929,8 & 28,00 & 4,043 & $\begin{array}{c}\text { Signifikan } \\
\left(\mathrm{t} \mathrm{t}_{\mathrm{ht}}>\mathrm{t}_{\mathrm{tbl}}\right)\end{array}$ \\
\hline Sisa & 28 & 1525,86 & 54,49 & & & \\
\hline
\end{tabular}




\begin{tabular}{|c|c|c|c|c|c|c|}
\hline $\begin{array}{c}\text { Sumber } \\
\text { Varian }\end{array}$ & dk & JK & KT & F hitung & $\begin{array}{c}\mathbf{F} \text { tabel } \\
\alpha=\mathbf{0 , 0 5}\end{array}$ & Keterangan \\
\hline $\begin{array}{c}\text { Tuna } \\
\text { Cocok }\end{array}$ & 18 & 1466,00 & 77,13 & 0,782 & 4,325 & $\begin{array}{c}\text { Signifikan } \\
\left(\mathrm{t}_{\mathrm{ht}}<\mathrm{t}_{\mathrm{tbl}}\right.\end{array}$ \\
\hline Galat & 12 & 603,17 & 60,32 & & & Linear \\
\hline
\end{tabular}

Berdasarkan rangkuman hasil perhitungan tabel 1 diperoleh $F_{\text {hitung }}$ untuk keberartian model regresi 28,00. Sementara $F_{\text {tabel }} \alpha=0,05$ adalah 7,194. Dengan demikian dapat dinyatakan bahwa persamaan regresi $\hat{\mathbf{Y}}=\mathbf{5 7 , 9 0}+\mathbf{0 , 4 9} \mathrm{X}_{\mathbf{1}} \mathrm{Y}$ adalah signifikan, karena $F_{\text {hitung }}>F_{\text {tabel }}$. Sedangkan untuk uji linearitas diperoleh angka $F_{\text {hitung }}$ sebesar 0,7820. Angka ini ternyata lebih kecil dari $F_{\text {tabel }}$ pada $\quad \alpha=0,05$ yang besarnya adalah 8,017 , berarti hubungan tersebut adalah linear. Keberartian linearitas tersebut dapat digunakan sebagai syarat untuk memberikan kesimpulan dalam rangka menjelaskan hubungan antara pelaksanaan KKG dengan kemampuan merencanakan pembelajaran.

Uji keberartian koefisien arah regresi dilakukan dengan uji t. Hasil perhitungan diperoleh $t_{\text {hitung }}$ sebesar 45,008. Sedangkan $t_{\text {tabel }}$ untuk $\alpha=0,05$ adalah 2,01063 berarti koefisien arah regresi 0,49 adalah signifikan.

2. Hubungan antara Variabel Motivasi Kerja $\left(\mathrm{X}_{2}\right)$ Kemampuan Merencanakan Pembelajaran (Y)

Hipotesis kedua yang diajukan adalah "terdapat hubungan antara yang berarti antara kemampuan merencanakan pelajaran terhadap pelaksanaan pembelajaran". Berdasarkan analisis data yang telah dilakukan terhadap hubungan variabel $\mathrm{X}_{2}$ dan $\mathrm{Y}$ diperoleh $r=0,609 ; r^{2}=0,3718$. Setelah dilakukan uji $t$ diperoleh $t$ hitung $=4,0705$. Sedangkan $t_{\text {tabel }}$ pada taraf $\alpha=0,05$ sebesar 2,0422. Dari angka-angka tersebut ternyata dihasilkan $\mathrm{t}_{\text {hitung }}>\mathrm{t}_{\text {tabel }} \alpha=0,05$. Hal ini berarti bahwa $\mathrm{H}_{\mathrm{o}}$ ditolak dan konsekuensinya $\mathrm{H}_{\mathrm{a}}$ diterima. Dengan demikian dapat disimpulkan bahwa terdapat Hubungan antara yang signifikan variabel kemampuan merencanakan pembelajaran $\left(\mathrm{X}_{2}\right)$ terhadap pelaksanaan pembelajaran (Y). Dari angka di atas juga dapat ditafsirkan kekuatan hubungan sebesar 0,609 dengan diterminasi $r^{2}=0,3718(37,18 \%)$.

Apabila dilakukan pengontrolan terhadap variabel bebas yang lain, maka diperoleh koefisien korelasi parsial $r_{\mathrm{y}} 2-1$ sebesar 0,620 dengan koefisien diteminasi $\mathrm{r}^{2}$ $=0,3842$. Setelah dilakukan uji $\mathrm{t}$, diperoleh $\mathrm{t}_{\text {hitung }}=5,4115$. Sedangkan $\mathrm{t}_{\text {tabel }}$ pada taraf $\alpha=0,05$ sebesar 2,0117. Dari angka-angka tersebut ternyata $t_{\text {hitung }}>t_{\text {tabel }} \alpha=0,05$. Koefisien korelasinya menunjukkan bahwa bila dilakukan pengontrolan terhadap variabel bebas yang lain dalam hubungan $\mathrm{x}_{2}-\mathrm{y}$, ternyata tidak terjadi perubahan kadar hubungan antara keduanya. Artinya hubungan kedua variabel tersebut tetap signifikan meskipun dilakukan pengontrolan terhadap variabel lainnya. Hal ini diperkuat oleh Hubungan antara variabel $\mathrm{X}_{2}$ sebesar $38,42 \%$ terhadap $\mathrm{Y}$.

Berikutnya dilakukan analisis regresi sederhana untuk mengetahui keberartian hubungan yang terjadi. Berdasarkan hasil perhitungan (Lampiran tabel L. 19) model 
regresi hubungan antara kemampuan merencanakan pembelajaran dengan pelaksanaan pembelajaran (Y) dapat dinyatakan dalam bentuk persamaan $\hat{\mathbf{Y}}=\mathbf{1 1 , 2 5}+\mathbf{0 , 8 8} \mathbf{X}_{2}$.

Untuk menguji keberartian dan linearitas hubungan antara $\mathrm{X}_{2}$ dengan $\mathrm{Y}$ tersebut dilakukan analisis varians. Perhitungan secara lengkap dibahas pada lampiran 13 dan rangkuman hasilnya disajikan dalam tabel 2 di bawah ini;

\section{Tabel 2}

Hasil Analisis Varians Regresi Linear $\mathrm{X}_{2}$ dan $\mathrm{Y}$

$\hat{\mathbf{Y}}=\mathbf{1 1 , 2 5}+\mathbf{0 , 8 8} \mathrm{X}_{2}$

\begin{tabular}{|c|c|c|c|c|c|c|}
\hline $\begin{array}{c}\text { Sumber } \\
\text { Variansi }\end{array}$ & $\mathbf{d k}$ & $\boldsymbol{J K}$ & $\boldsymbol{K T}$ & $\mathbf{F}$ hitung & $\begin{array}{c}\mathbf{F} \text { tabel } \\
\boldsymbol{\alpha = \mathbf { 0 , 0 5 }}\end{array}$ & Ket \\
\hline Total (T) & 30 & 369501,4 & & & & \\
\hline Regresi (a) & 1 & 14050,15 & - & - & - & \\
\hline Regresi (b/a) & 1 & 369501,4 & 369501,4 & 28,000 & 7,194 & Signifikan \\
\hline Sisa & 28 & 1282,40 & 45,80 & & & \\
\hline Tuna Cocok & 12 & 1250,13 & 56,82 & 0,56817 & 8,017 & Signifikan \\
\hline Galat & 18 & 452,00 & 32,29 & & & \\
\hline
\end{tabular}

Berdasarkan rangkuman hasil perhitungan tabel 11 diperoleh $F_{\text {hitung }}$ untuk keberartian model regresi sebesar 28,000. Sementara $F_{\text {tabel }}$ untuk $\alpha=0,05$ adalah 7,194. Dengan demikian dapat dinyatakan bahwa persamaan regresi $\hat{Y}=11,25+0,88$ $\mathrm{X}_{2}$ adalah signifikan, karena $\mathrm{F}_{\text {hitung }}>\mathrm{F}_{\text {tabel }}$. Sedangkan untuk uji linearitas diperoleh angka sebesar 0,5681 . Angka ini ternyata lebih kecil dari $F_{\text {tabel }}$ pada $\alpha=0,05$ yang besarnya adalah 8,017, berarti hubungan tersebut adalah linear. Keberartian linearitas tersebut dapat digunakan sebagai syarat untuk memberikan kesimpulan dalam rangka menjelaskan hubungan antara kemampuan merencanakan pelajaran dengan pelaksanaan pembelajaran.

Uji keberartian koefisien arah regresi dilakukan dengan uji t. Berdasarkan perhitungan pada lampiran tabel L.19, diperoleh thitung sebesar 80,9076. Sedangkan $t_{\text {tabel }}$ untuk $\alpha=0,05$ adalah 2,01061, berarti koefisien arah regresi 11,25 adalah signifikan.

3. Hubungan antara Pelaksanaan KKG $\left(X_{1}\right)$ dan Motivasi Kerja $\left(X_{2}\right)$ Secara Bersamasama Terhadap Kemampuan Merencanakan Pelajaran (Y)

Hipotesis ketiga adalah "Terdapat Hubungan yang berarti antara pelaksanaan KKG dan motivasi kerja secara bersama-sama terhadap kemampuan merencanakan pembelajaran. Hal ini dapat dilihat pada tabel rangkuman hasil analisi regresi ganda variabel $\mathrm{X}_{1}$ dan $\mathrm{X}_{2}$ dengan $\mathrm{Y}$ di bawah ini. 
Tabel 3

Rangkuman Hasil Analisis Regresi Ganda

Variabel $X_{1}$ dan $X_{2}$ dengan $Y$

\begin{tabular}{|c|c|c|c|c|c|}
\hline $\begin{array}{c}\text { Hubungan } \\
\text { antar } \\
\text { Variabel }\end{array}$ & $\begin{array}{c}\text { Koefisien } \\
\text { Korelasi } \\
(\mathrm{r})\end{array}$ & $\begin{array}{c}\text { Koefisien } \\
\text { Diterminasi } \\
\left(\mathrm{r}^{2}\right)\end{array}$ & $\mathrm{F}_{\text {hitung }}$ & $\begin{array}{c}\mathrm{F} \text { tabel } \\
\alpha=0,05\end{array}$ & Keterangan \\
\hline $\mathrm{Ry}_{1.2}$ & 0,734 & 0,5395 & 15,816 & 3,3403 & Signifikan \\
\hline
\end{tabular}

Berdasarkan analisis data yang telah dilakukan tentang hubungan variabel $\mathrm{X}_{1}$ dan $\mathrm{X}_{2}$ secara bersama terhadap $\mathrm{Y}$ diperoleh $\mathrm{r}=0,734 ; \mathrm{r}^{2}=0,5395$. Setelah dilakukan uji $F$ diperoleh $F_{\text {hitung }}=15,816$. Sedangkan $F_{\text {tabel }}$ pada taraf adalah $\alpha=0,05$ sebesar 3,3403. Dari angka-angka tersebut ternyata dihasilkan $F_{\text {hitung }}>F_{\text {tabel }}$ pada taraf $\alpha=$ 0,05. Hal ini berarti bahwa $\mathrm{H}_{\mathrm{o}}$ ditolak dan sekaligus menerima $\mathrm{H}_{\mathrm{a}}$. Dengan demikian dapat disimpulkan bahwa terdapat Hubungan yang signifikan pelaksanaan $\mathrm{KKG}\left(\mathrm{X}_{1}\right)$ dan Motivasi kerja $\left(\mathrm{X}_{2}\right)$ terhadap kemampuan merencanakan pelajaran (Y). Dari angka di atas juga dapat ditafsirkan kekuatan hubungan $\mathrm{r}$ sebesar 0,703 dengan diterminasi hubungan $\mathrm{r}^{2}=0,5395(53,95 \%)$.

Berikutnya dilakukan analisis regresi ganda untuk mengetahui keberartian hubungan yang terjadi. Berdasarkan hasil perhitungan Lampiran tabel 17a model regresi ganda hubungan antara pelaksanaan $\mathrm{KKG}\left(\mathrm{X}_{1}\right)$ dan motivasi kerja secara bersama-sama terhadap kemampuan merencanakan pelajaran (Y) dapat dinyatakan dalam bentuk persamaan $\hat{\mathbf{Y}}=\mathbf{2 7 , 1 3 + 0 , 4 1} \mathbf{X}_{1}+\mathbf{0 , 7 8} \mathbf{X}_{2}$.

Untuk menguji keberartian dan linearitas hubungan antara $\mathrm{X}_{1}$ dan $\mathrm{X}_{2}$ dengan $\mathrm{Y}$ tersebut dilakukan analisis varians. Perhitungannya secara lengkap dibahas pada lampiran tabel L.17 dan rangkuman hasilnya disajikan dalam tabel 4.

Tabel 4

Rangkuman Hasil Uji Keberartian Regresi Ganda $X_{1}$ dan $X_{2}$ dengan $Y$ $\hat{\mathbf{Y}}=\mathbf{2 7 , 1 3}+\mathbf{0 , 4 1} \mathrm{X}_{1}+\mathbf{0 , 7 8} \mathrm{X}_{2}$

\begin{tabular}{|c|c|c|c|c|c|c|}
\hline $\begin{array}{c}\text { Sumber } \\
\text { Variansi }\end{array}$ & dk & JK & KT & $\mathbf{F}_{\text {hitung }}$ & $\begin{array}{c}\text { F tabel } \\
\alpha=\mathbf{0 , 0 5}\end{array}$ & Kete \\
\hline Regresi & 2 & 1099,21 & 2037,5 & 20,356 & 3,1951 & Signifikan \\
\hline Sisa & 28 & 938,26 & 395,948 & & & \\
\hline
\end{tabular}

Berdasarkan tabel di atas diperoleh $\mathrm{F}_{\text {hitung }}$ untuk uji keberartian model regresi ganda 20,356. Sementara $F_{\text {tabel }}$ untuk $\alpha=0,05$ adalah 3,1951. Dengan demikian dapat 
dinyatakan bahwa persamaan regresi ganda $\hat{\mathbf{Y}}=\mathbf{2 7 , 1 3}+\mathbf{0 , 4 1} \mathbf{X}_{\mathbf{1}}+\mathbf{0 , 7 8} \mathbf{X}_{\mathbf{2}}$ adalah signifikan, karena $F_{\text {hitung }}>F_{\text {tabel }}$.

Sedangkan untuk uji keberartian koefisien persamaan regresi ganda dengan uji $\mathrm{t}$, diperoleh angka sebesar 2,8973 dan 3,7923. Angka ini ternyata lebih besar dari $t_{\text {tabel }}$ pada $\alpha=0,05$ yang besarnya 2,0117 , berarti koefisien regresi ganda persamaan $\hat{\mathbf{Y}}=$ $\mathbf{2 7 , 1 3}+\mathbf{0 , 4 1} \mathrm{X}_{\mathbf{1}}+\mathbf{0 , 7 8} \mathrm{X}_{\mathbf{2}}$ tersebut adalah signifikan.

Untuk mengetahui perbandingan serta efektifitas dukungan tiap variabel bebas, maka perhitungan tersebut dilanjutkan dengan mencari sumbangan relatif (sr) dan sumbangan efektif (se) masing-masing prediktor terhadap variabel pelaksanaan pembelajaran. Hasil perhitungan lebih rinci dijelaskan pada lampiran tabel L.15 dan rangkumannya disajikan dalam tabel 5.

\section{Tabel 5}

Rangkuman Hasil Perhitungan Sumbangan Relatif dan Sumbangan Efektif Variabel $X_{1}$ dan $X_{2}$

\begin{tabular}{|l|c|c|}
\hline \multicolumn{1}{|c|}{ Nama Prediktor } & SR (\%) & SE (\%) \\
\hline Pelaksanaan KKG & 38,62 & 20,84 \\
\hline Motivasi Kerja & 61,38 & 33,11 \\
\hline
\end{tabular}

Sumbangan relatif (tabel 13) variabel $\mathrm{X}_{1}\left(\mathrm{SR}_{1}\right)=38,62 \%$ dan variabel $\mathrm{X}_{2}\left(\mathrm{SR}_{2}\right)$ $=61,38 \%$. Sementara itu sumbangan efektif variabel $\mathrm{X}_{1}\left(\mathrm{SE}_{1}\right)=20,84 \%$ dan variabel $\mathrm{X}_{2}\left(\mathrm{SE}_{2}\right)=33,11 \%$. Berarti sumbangan efektif kedua variabel bebas tersebut adalah $20,84 \%+33,11 \%=53,59 \%$. Sumbangan efektif kedua variabel sebesar 53,95\% di atas cukup meyakinkan, mengingat banyaknya variabel lain yang mempengaruhi kemampuan merencanakan pembelajaran yang dilakukan oleh seorang guru.

\section{PEMBAHASAN}

Pengujian hipotesis pertama, kedua dan ketiga menunjukkan bahwa semua hipotesis diterima. Hasil pengujian hipotesis pertama mengindikasikan bahwa persepsi guru tentang pelaksanaan KKG memiliki Hubungan yang berarti (signifikan) kemampuan merencanakan pembelajaran. Hubungan ini terlihat dari angka korelasi $\left(r_{y .1}\right)=0,502$ dengan koefisien diterminasi sebesar 0,2521 pada taraf $\alpha=0,05$. Koefisien deteminasi sebesar 0,2521 menunjukkan bahwa pelaksanaan musyawarah KKG sebagai faktor penentu dalam merencanakan pembelajaran dengan hubungan sebesar $25,21 \%$. Berarti terdapat Hubungan yang positif dan signifikan antara pelaksanaan Musyawarah KKG terhadap Kemampuan Merencanakan Pembelajaran. Dengan kata lain semakin tinggi nilai yang diperoleh dalam pelaksanaan Musyawarah KKG semakin baik pula kemampuan Perencanaan Pembelajaran yang dilakukan seorang guru . Bentuk hubungannya dinyatakan dengan persamaan $\hat{Y}=57,90+0,49$ $\mathrm{X}_{1}$. Model persamaan regresi terebut mengandung arti bahwa apabila skor pelaksanaan Musyawarah KKG naik satu satuan, maka kemampuan merencanakan pembelajaran akan meningkat 0,49 satuan pada konstanta 57,90. 
Jika dilakukan kontrol terhadap variabel Motivasi Kerja $\left(\mathrm{X}_{2}\right)$, maka diperoleh hubungan parsial antara pelaksanaan $\mathrm{KKG}\left(\mathrm{X}_{1}\right)$ dengan kemampuan merencanakan pembelajaran (Y) dengan koefisien korelasi parsial sebesar 0,516. Hal ini menunjukkan bahwa tidak terjadi penurunan kadar hubungan antara pelaksanaan KKG dengan kemampuan merencanakan pembelajaran, yang berarti bahwa variabel $\mathrm{X}_{1}$ bukanlah satu-satunya variabel yang dapat menentukan keberhasilan pelaksanaan pembelajaran, melainkan masih ada variabel lain yaitu motivasi kerja guru.

Pengujian hipotesis kedua juga menunjukkan bahwa motivasi kerja mempunyai hubungan yang berarti terhadap kemampuan merencanakan pembelajaran. Hubungan ini terlihat dari angka korelasi $\left(\mathrm{r}_{\mathrm{y} .2}\right)=0,609$ dengan koefisien diterminasi sebesar 0,3718 pada $\alpha=0,05$. Koefisien diteminasi sebesar 0,3718 menunjukkan bahwa motivasi kerja merupakan salah satu faktor penentu dalam perencanaan pembelajaran dengan hubungannya sebesar 37,18\%. Berarti terdapat Hubungan yang positif dan signifikan antara motivasi kerja terhadap kemapuan merencanakan pembelajaran. Dengan kata lain semakin tinggi motivasi kerja, maka semakin meningkat pula kemampuan merencanakan pembelajaran. Bentuk hubungannya dinyatakan dengan persamaan $\hat{\mathrm{Y}}=11,25+0,88 \mathrm{X}_{2}$.

Jika dilakukan pengontrolan terhadap variabel lain dalam hal ini adalah pelaksanaan $\mathrm{KKG}\left(\mathrm{X}_{1}\right)$, maka diperoleh hubungan parsial antara Motivasi kerja $\left(\mathrm{X}_{2}\right)$ dan Kemampuan Merencanakan Pembelajaran (Y) dengan koefisien korelasi parsial sebesar 0,619. Hal ini menunjukkan bahwa tidak terjadi penurunan kadar hubungan antara motivasi kerja dengan kemampuan merencanakan pembelajaran, yang berarti bahwa variabel $\mathrm{X}_{2}$ bukanlah satu-satunya variabel yang dapat menentukan kemampuan perencanaan pembelajaran, melainkan masih ada variabel lain yakni pelaksanaan musyawarah kelompok kerja guru (KKG).

Hasil pengujian hipotesis ketiga, pelaksanaan musyawarah Kelompkk kKerja Guru (KKG) dan motivasi kerja secara bersama-sama mempunyai hubungan yang berarti terhadap kemampuan merencanakan pembelajaran. Besarnya hubungan tersebut ditunjukkan oleh koefisien korelasi $\mathrm{r}$ sebesar 0,703 dengan uji $\mathrm{F}$, di mana $\mathrm{F}$ hitung $15,816>\mathrm{F}$ tabel 3,3403 pada taraf $\alpha=0,05$. Hubungan tersebut dinyatakan dalam bentuk persamaan regresi $\hat{Y}=27,13+0,41 \mathrm{X}_{1}+0,78 \mathrm{X}_{2}$. Hal ini berarti bahwa terdapat Hubungan yang positif antara pelaksanaan musyawarah kelompok kerja guru (KKG) dan motivasi kerja secara bersama-sama terhadap kemampuan merencanakan pembelajaran. Dengan kata lain jika secara bersama-sama pelaksanaan KKG dan motivasi kerja ditingkatkan satu satuan, maka kemampuan merencanakan pembelajaran cenderung meningkat sebesar $(0,41+0,78)=1,19$ satuan pada konstanta 27,13 .

Kemudian koefisien diterminasi 0,4947 menunjukkan bahwa pelaksanaan musyawarah kelompok kerja guru (KKG) dan motivasi kerja secara bersama-sama mempunyai peranan yang cukup menentukan terhadap kemampuan merencakan pembelajaran, yaitu dengan hubungan sebesar 49,47 \%. Berarti bahwa kemampuan merencanakan pembelajaran dapat dijelaskan oleh pelaksanaan musyawarah kelompok kerja guru (KKG) dan motivasi kerja sebesar 49,47\%. 
Hasil penelitian ini mendukung pendapat yang mengatakan bahwa jika guru yang mengikuti Muswarah Kerja Guru (KKG) memiliki motivasi kerja yang tinggi, maka ia akan dapat merencanakan perbelajarannya dengan baik pula.

\section{KESIMPULAN}

Berdasarkan hasil penelitian dapat disimpulkan :

1. Pelaksanaan musyawarah Kelompk Kerja Guru berkontribusi sebesar 25,21\% terhadap kemampuan merencanakan pembelajaran. Bila skor pelaksanaan musyawarah semakin tinggi maka akan semakin baik perencanaan pembelajaran oleh guru.

2. Motivasi kerja berkontribusi sebesar $37,18 \%$. Hal ini berarti terdapat Hubungan yang positif dan signifikan antara motivasi kerja terhadap kemapuan merencanakan pembelajaran. Dengan kata lain semakin tinggi motivasi kerja, maka semakin meningkat pula kemampuan merencanakan pembelajaran.

3. Pelaksanaan Musyawarah Kelompok Kerja Guru (KKG) dan Motivasi Kerja secara bersama-sama mempunyai peranan yang cukup menentukan terhadap kemampuan merencakan pembelajaran, dengan nilai kontribusi sebesar 49,47\%. Hal ini berarti bahwa kemampuan merencanakan pembelajaran dapat dijelaskan oleh pelaksanaan musyawarah Kelompk Kerja Guru dan Motivasi Kerja sebesar 49,47\%.

4. Hasil penelitian ini mendukung pendapat yang mengatakan bahwa jika guru yang mengikuti Muswarah Kerja Guru (KKG) memiliki motivasi kerja yang tinggi, maka ia akan dapat merencanakan perbelajarannya dengan baik pula.

\section{DAFTAR PUSTAKA}

Arikunto. Suharsimi. (1996). Dasar-Dasar Evaluasi Pendidikan. Jakarta : Bumi Aksara.

(1996). Prosedur Penelitian (Suatu Pendekatan Praktek). Jakarta : Rineka Cipta.

Bandura. (1977). Self-efficacy : Toward a unifying theory of behavioral change/ Psychological review.

Bloom, Benyamin. S,. (Eds). (1980). The New Direction in Edicational Research : Alternatif Variables. Phi Delta Kappan.

Chaplin, W. G. (1989) Kamus Lengkap Psikologi. Terjemahan. Jakarta : Rajawali.

Cochran, Wiliam, G. (1974). Sampling Techniques. New Delhi : Eastern Privade Limited. York.

Dharma. Agus, (1985). Manajemen Prestasi Kerja : Pedoman Praktis Bagi Para Penyedia Untuk Meningkatkan Prestasi Kerja: Jakarta, Rajawali.

Depdikbud, (1984). Buku Petunjuk Administrasi Program Pengajaran Sekolah Dasar. Jakarta : Dirjen Pendidikan Dasar dan Menengah.

---------,(1996). Buku Petunjuk Peningkatan Mutu Pendidikan di Sekolah Dasar. Jakarta Dirjen Pendidikan Dasar dan Menengah. 
, (1994/1995). Pedoman Pembinaan Profesional Guru Sekolah Dasar. Jakarta : Dirjen Pendidikan Dasar dan Menengah.

, (1996/1997). Pedoman Pembinaan Profesional Guru sekolah Dasar. Jakarta

: Dirjen Pendidikan Dasar dan Menengah

--------- , (1997). Pengenalan Terhadap Alat Penilaian Kemampuan Guru (APKG) :

Rencana Pengajaran. Jakarta : Proyek pengembangan Pendidikan guru

Dick, W dan Carey, L. (1985). The Systematic Design of Instruction. Secon edition.

Chicago : Rand Mc Nally College Publishing Company.

Effendy, O. U. (1989). Psikologi Manajemen Administrasi. Bandung: Mandar Maju. Imron, Ali. (1995). Pembinaan Guru di Indonesia. Jakarta : Pustaka Jaya.

Jasin, Anwar. (1996). Pembelajaran Efektif. Jakarta : Grasindo.

Kemp, Jerrol. E. (Terjemahan Asril Marjohan). (1994). Proses perancangan pengajaran. Bandung : Penerbit ITB.

McCelland, David. (1995). Bussiness drive and national achievement. New

York: Harvard Businees Review

Moekijat. (1988). Asas-asas Perilaku Organisasi. Bandung : Mandar Maju.

Mudjito, (1988). Manajemen Sekolah Dasar : Jati bening dua : Inti buku utama.

Maizuar. (1997). Kemampuan Mengajar Guru STM di Sumatera Barat. Jakarta :

Disertasi. Program Pascasarjana IKIP Jakarta.

Sudjana. (1982). Metode Statistik Bandung: Tarsito.

Sunyoto, A. (1995). Manajemen sumber daya manusia. Jakarta: Badan Penelitian IPWI.

Suciati dan Irawan, P. (1993). Program Pengembangan Keterampilan Dasar Teknik Instruksional (PEKERTI) Untuk Dosen Muda. Suplemen 1. Dikti Depdikbud.

Sardiman. (2000). Interaksi Dan Motivasi Belajar Mengajar. Jakarta: Rajawali.

Sanusi. A. dkk. (1991). Studi Pengembangan Model Pendidikan Profesional Tenaga Kependidikan. Bandung : Depdikbud IKIP.

Udai, Preek. (1984). Prilaku Organisasi. Jakarta: Binaman Pressindo.

Winardi, (1996). Manajemen Supervisi. Bandung: Mandar Maju. 